\title{
Researching Latvian Child Language
}

\section{Summary \\ Introduction}

The scientific article is an analytical overview of history of child language as new research branch launched in Latvia, indicating significance and future perspective of this direction.

\section{Aim of the study}

The aim of the research is to analyse and substantiate the history, strategy and perspective of child's language studies in Latvia.

\section{Materials and methods}

The traditional methods used in researches of child language in Latvia - research observation, questionnaires, theoretic analysis of interviews, writing down and classification of vocabulary in form of dictionaries, approbation of conclusions in meetings and reviews, as well as instrumental speech analysis methods.

The article uses materials on previous research of child's language in Latvia.

\section{Results}

Before establishment of the Child's Language Research Centre of the Riga Teacher Training and Educational Management Academy (RTTEMA), mostly separate articles were dedicated to child language studies in Latvia. In September 2006, regulations of the Child's Language Research Centre were approved by decision of Senate of the Riga Teacher Training and Educational Management Academy, and on 5 January 2007, the centre was officially registered at the Ministry of Education and Science. Researchers have worked with the following branches: child's language in mixed families, enrichment of child's language in circumstances of culture interaction and society consolidation, child multilingualism in Latvia, signs of social changes in child language, games and plays for development of child language, language in fiction and teaching aids for children, marks of child literary creativity, child language as an object of philological research and typology of child language. The field of research has been extended to analysis of adolescent language, as well as solutions for development and perfection of child language are being searched in cooperation with specialists from psychology and language pathology.

Results of child language studies are published in monographs, one collection of articles and many articles, as well as works of popular-science; recommendations have been provided to specialists of preschool education and children's parents. Samples and records of children's speech at various ages are collected and analysed, the first dictionary of child's language has been prepared for publication; this empiric material will be of use for researchers of various fields. Approbation of methods for acoustic analysis of child's language is carried out.

\section{Conclusions}

As a result of activities of the Child's Language Research Centre of the Riga Teacher Training and Educational Management Academy research of child' language in Latvia has developed into purposeful and stable field of research.

This is a complex field of research based on results acquired by specialists from pedagogy, linguistics and psychology.

Language serves needs of child's expression and communication in compliance with the individual world of emotions, concepts, initial notions and attitude. To study this particularity and its gradual alignment with mental activities of grown-up people is a significant research task providing contribution to development of linguistics and pedagogy as well as other fields related to child's raising and development.

Key words: Complex research object, research fields and missions. 


\section{Introduction}

The scientific article is an analytical overview of history of child language as new research direction launched in Latvia, indicating significance and future perspective of this direction. Research on Latvian children language have previously been related to the name of Professor Velta Rūḳe-Draviņa (1917-2003). Productively working in various subfields of linguistics, the Professor had dedicated herself to research of Latvian child language since 1950, paying special attention to processes of language formation and changes in an individual's life. A more known V. Rūke-Dravina's work is the monograph From 5 Months to 5 Years (1982) where the author has followed in a form of a diary the way a child learns the native Latvian language. The book, issued in 1982 in Stockholm, later was also published in Latvia. Additionally, V. Rūḳe-Dravina tells of child language in several articles (Ruke-Dravina 1963; 1967) and book Latvian Girl Learns Her First Language (1993) and manuscript Story of the Little Red Riding Hood Told by Parents and Child. Influence of Surroundings to Language Development (1995) which was granted to the Riga Teacher Training and Educational Management Academy. This manuscript in a form of a brochure is available to readers at the academy library since 1995. The author of the manuscript describes child language development, for example, how a child gradually turns into a reader from a questioner, and how parents adopt their language to development of the child's language. The Latvian-born Professor performed the researches of child language in Sweden, thus language development of Latvian children living in exile was studied. For a long time these were the only studies of Latvian child's language to base linguistic and pedagogical recommendation on.

\section{Aim of the study}

Aim of the research is to analyse and substantiate history, strategy and perspective of study of child's language in Latvia.

\section{Materials and methods}

The traditional methods used in researches of child's language in Latvia - research observation, questionnaires, theoretic analysis of interviews, writing down and classification of vocabulary in form of dictionaries, approbation of conclusions in meetings and reviews, as well as instrumental speech analysis methods.

The article uses materials on previous researches of child's language in Latvia.

\section{Results}

Prior to establishment of the Child's Language Research Centre of the Riga Teacher Training and Educational Management Academy, only separate articles were devoted to child's language research (Markusa Bērziña 1991; Markus 1991; Markus 1997; Markus 2000; Markus 2002; Dzintere 2005; Freiberga 2006; Freidenfelds 2006; Vecmane 2006; Vulāne 2006); no purposeful research field existed. In 2003, the book Child's Language: from the First Cry to a Story by D. Markus was issued. This book collects and analyses language examples of children living in Latvia from the point of view of traditional linguistics, drawing attention also to the child's creative language activity, imaginative thinking and emotionally aesthetic world perception. A study course Child Language was launched at the University of Latvia and the Riga Teacher Training and Educational Management Academy. Publishing of separate articles was also continued. A significant turn in research of child language took place in 2005 when state research program Latvian Studies: Research on History, Language and Culture acquired funding for research subproject Features of Age Group Language in Latvia: Linguistic, Social and Culture Aspect. For development of this sub-project, a group of researchers was established at the Riga Teacher Training and Educational Management Academy; the group included specialists of linguistics, psychology and pre-school pedagogy. The group initiated researches of child's language in various fields. The funding granted to the sub-project confirmed the interest of state scientific society and care for development of the mentioned 
field. The very first research results revealed that the group of researchers including specialists from the Riga Teacher Training and Educational Management Academy, the University of Latvia and Rēzekne Higher Education Institution can become a research centre for child language in Latvia. In September 2006, regulations of the Child's Language Research Centre were approved by decision of Senate of the Riga Teacher Training and Educational Management Academy, and on 5 January 2007, the centre was officially registered at the Ministry of Education and Science, thus commencing the purposeful activities of the centre. Significance of establishing the Child's Language Research Centre of the Riga Teacher Training and Educational Management Academy exactly for such institution of higher education where teachers to become and managers of educational work are studying can be compared with organization of the Institut J. J. Rousseu: "When we opened this institute in 1912, it was hoped that the two main pillars upon which we intended to build the edifice-the scientific study of the child and the training of teacherswould not remain isolated, but be spanned and mutually reinforced by many connecting arch. But the cares of organization, the unexpected developments of an undertaking which receives fresh impetus and grows faster than one had calculated, the requirements of daily teaching, to say nothing of the disturbances caused by the war-all these have prevented our scientific investigations from proceeding as we would have wished"(Clapared 2008, ix). This very institute became one of most successful organisation for development of ideas and theories by the remarkable scientist J. Piaget. Sixteen researchers now work at the Child's Language Research Centre of the Riga Teacher Training and Educational Management Academy: linguists, pedagogues and psychologists, twelve of them are doctors of science, three are candidates for doctor's degree, and one employee takes care of technical processing. Unfortunately, the leading researcher I. Freidenfelds has passed away.

The work concept of the centre stresses that child language is a complex research object; however it is not a simplified miniature of adult language. This language serves the needs of child's expression and communication in compliance with the individual world of emotions, concepts, initial notions and attitude. To study this feature and its gradual alignment with mental activities of grown-up people can be a significant research task providing contribution to development of linguistics and pedagogy as well as other fields related to child's raising and development. "It is important that the child speaks, reads, retells, and likewise important is the language the child uses and his own attitude towards the spoken material and whether the child can see the beauty not only from outside, which he wishes to describe by words, but also in words by which he describes the surroundings" (Markus 2003, 73).

One of tasks for the centre workers is preparation of child's language data base. Writing down, storing and classifying the specific vocabulary used by children in a form of dictionary has begun; in future recording of child's speech and its acoustic analysis is planned. Such data basis would reflect the state of the Latvian language in the 21 st century and its acquisition at the age group of children.

The most planned and already used research methods are research observation, questionnaires, theoretic analysis of interviews, writing down and classification of vocabulary in form of dictionaries, approbation of conclusions in meetings and reviews, as well as instrumental speech analysis methods. Students of the Riga Teacher Training and Educational Management Academy have engaged in recording children's vocabulary; they write down child language during pedagogical praxis at pre-school pedagogical institutions. Children are being interviewed, asked how they understand various concepts from everyday life, from folklore, textbooks and other sources. Analysis of these materials is included in D. Markus'book Child Speaks in Culture World (Markus 2007) and several articles (Markus, Degtjarjova 2006; Маркус 2007; Markus 2008, 92-97; Markus 2008, 16; Markus 2008, 220-224). Since speech development is affected by several factors, for example, child's psycho-physiological development, psychological and social environment in family, parents' attitude and others, one can expect that the level of language competency within one age group would differ significantly; therefore the material acquired by various research methods will not be homogeneous. Use of instrumental speech analysis methods in researches of child language in Latvia is a novelty. It has become possible thanks to establishment of the Child's Language Research Centre at the RTTEMA because equipment necessary for quality sound recording and acoustic analysis has been acquired by the centre. Development of methodology takes place in order to choose the most appropriate approaches to analysis of children's speech. The approaches are practically approbated by collecting and analysing recordings of speech by children of various age groups. 
Feature of child's speech recording, which burdens spectral analysis, is the high basic fundamental frequency $(250-450 \mathrm{~Hz})$. Since spectral analysis must use filter in order to acquire image of formants rather than separate harmonics and the filters should have a band width at least two times larger than the value of the fundamental frequency, the filter band widths for analysis of illustrated speech sample should be at least $765 \mathrm{~Hz}$; however the closest formants would not be mutually separable, they would form uniform energy zones. This would make determination of precise formant frequencies difficult and would delay interpretation of the acoustic signal. Explanation on relation of acoustic signal with the values of resonator's resonance created by speech organs would be made difficult. Usually children's speech formant bands are wide and unclear.

One possible solution in such case would be use of inverse filtering to separate sound source and features characterising the resonator in a speech signal. Correctness of resonator's characteristic could be verified if a new sound is synthesized by using the values characteristic of the resonator in connection with basic tone of low frequency $(100 \mathrm{~Hz})$.

Scientists of the Child's Language Research Centre of the RTTEMA have made this as the task of their near future. Data basis of acoustic research would allow tracing the typical values characteristic of speech of children of various age and defining sound pronunciation norm corresponding to each age which should be compared by pronunciation mistakes and deviations reviewed at practice of speech therapy. Research data will be usable also for diagnosing pronunciation deviations and thus would improve and facilitate work of speech therapists.

General purpose of work by the Child's Language Research Centre is to develop research of child's language in Latvia, to facilitate perfection of study courses related to child's language researches. Results of the researchers' group have already been published in articles and reports at several local and international conferences and seminars. Authors have explained the tasks and results acquired by the centre also in popular-scientific publications and mass media. Basis for activity of the centre specialists is studies of special literature in order to find out the modern linguistic and pedagogic thought in research of child's language. In this regard, centre researchers' cooperation with the Childhood Institute of Herzen State Pedagogical University of Russia becomes very successful, especially with the Department of Child's Language. By the help of this department Latvian and Russian researchers of child's language exchange theory materials and share experience.

Lead by Professor S. Ceitlina, linguists and students of St. Petersburg study child's language at the Department of Child Language within traditions of linguistics, as well as from the point of view of pedagogy and psychology, the child's language being a component of the child's overall development. The Childhood Institute of Herzen State Pedagogical University of Russia also implements a program of master studies Child Language where child's language specialists to-be from other countries would be invited to study; however financial problems persist. For example, Latvian students cannot acquire Erasmus scholarship for studies in St. Petersburg because Russia is not a member state of the European Union; in turn, Latvia and Russia have not concluded a mutual cross border treaty on supporting such cooperation.

Upon rapid widening of international connections, population migration and number of mixed marriages increase, and likewise parents' wish increases to teach several languages to their children during childhood. This facilitates the introduction of spontaneous and organised multilingualism. This is also facilitated by policy of the State language and other languages in the state. Scientists are not unanimous about influence of multilingualism on development of a personality and about order of language acquisition. Irrespective of opinion variety, it is clear that multilingualism is a sign of the present era and is likely to grow. Likewise one of work aspects at the Child's Language Research Centre established in the Riga Teacher Training and Educational Management Academy is children's multilingualism in Latvia. Results of most recent research in western countries suggest that simultaneous acquisition of several languages is possible and facilitates a more rapid development of the personality, keeping in mind that acquisition of foreign languages desires a stable basis of the first language.

Language is one of main ways of national culture existence. The factor of a unified language was especially important in the history of the Latvian nation, and it has still remained important. Modern, 
rich literary language, its perfected system of use norms is national pride, one of main cultural values, which enters child's speech with the speech of parents, relatives, friends and other people. Children not only imitate forms of adults' speech, but also give names to items, coin words, take active part in language games and plays, try to express their experience in language means, and this forms a basis for individual culture of a language. The child thus releases its language and linguistic skills. Thus language is an individual and nation-wide culture element. The Child's Language Research Centre plans to carry out research in the following fields: Child's language in mixed families, enrichment of child's language in circumstances of culture interactivity and public consolidation, signs of social changes in child's language, games and plays for development of child's language. The first reports have already been read in these fields, articles have been published by Ilmārs Freidenfelds, Inese Freiberga, Daina Dzintere, Dace Augstkalne, Margarita Kaltigina, Viktorija Kuzina; and Dace Markus, Irina Degtjarjova and Anna Vulāne have prepared publications and read reports within the planned research fields: child's language as object of philological research and typology of child's language.

The first studies have been launched on language in fiction and textbooks for children, teaching aids have been compared with similar ones in other countries (M. Kaltigina, V. Kuzina, A. Vulāne). In turn, traits of literary creativity of children at the preschool age are studied by I. Freiberga. She has already published findings that tales composed by children are childishly naïve but fresh sprouts of literary innovation of humanity. "This freshness and sweetness is granted exactly by the simple use of language, which is both laconic in its layout, and at the same time it reflects the childlike understanding of the artistic language using diminutives as the main figurative means of expression. Simple composition and calm form of narration attributes rhythm, harmony, entirety to the tales composed by children, irrespective of what variant of composition is used by the child" (Freiberga 2007, 35-36). The findings have been collected about purposeful use of diminutives in speech by much younger children: "Thus already at the age of three, the child not only feels and understands difference between the basic word and the diminutive or the diminutive, but also knows how to use these differences semantically, in order to create effect of seriousness and even tragic of a situation" (Markus 2003, 85). Research of diminutive use in child's speech has been launched also by A. Vulāne: "A diminutive which has been used at place and in time should in turn be regarded as means of formation of the child's emotional intellect. Nowadays, the emotional intellect has been allocated increasingly significant role within the system of preconditions for professional success, therefore it is important that we would wish, be able and could use the riches offered by the Latvian language and Latvian culture for full-fledged development of child's emotional world" (Vulāne 2007, 91).

The first results of child's language researches in Latvia are announced at I and II Congress of Latvian Studies, III international conference "Theory for Practice at Education of Modern Society" in Riga 2006 and at the conference dedicated to K. Barons "Childhood Experience: Cultural Aspects" on 31 October and 1 November 2006. During the previous conference, Ilmārs Freidenfelds, Viktorija Kuzina, Tija Zïrin,a, Dace Markus, Anna Vulāne, Margarita Kaltigina and Lilija Jurǵīte took a look at relation of child's language to folklore. Articles published later provided author's suggestions from nation pedagogy; they especially analysed artistic means of expression found in folksongs, which can be successfully used in enrichment and variety of child's language (Freidenfelds, Kuzina 2003, 43-55; Vulāne 2003, 79-92) and games as activators of speech skills at the age of infants (Zïrina 2007, 37-42).

The year of 2007 was especially fruitful for the centre researchers - a collection of articles was published on child's language in Latvia Language Features of Age Groups in Latvia: Linguistic, Social and Culture Aspect. Childhood, monograph by D. Markus Child Speaks in Culture World was issued, as well as seminar was organised for workers at pre-school education institutions, for teachers to become, linguists, pedagogues and psychologists interested in issues and problems of child's language, as well as several scientific and popular-scientific articles were published. On 21-22 May 2007, the workers of the Child's Language Research Centre of the RTTEMA shared experience at scientific conference "Problems of Ontolinguistics - 2007" («Проблемы онтолингвистики - 2007») in St. Petersburg.

Variety of opinions, approaches and directions should be respected at the centre research, therefore no uniform linguistic material is expected as the result; however, a set of individual and group studies 
of uniform theme should rather be expected, which then will be published by authors in planned monographs, article collections, separate articles, results will be made public in reports, the empirical and fact material will be accumulated. We hope that the findings will be a contribution to research of child's language and basis for development of this branch into a respectable research field.

People working at the Child's Language Research Centre have commenced to collect and publish the empiric material of child's language. For preparation of such material, the experience of linguists from St. Petersburg at preparation of similar collections of child's language was taken into account. The material thus will be available to researchers and interested parties for further use. It is impossible to foresee all possible aspects of child language research; however, the following year of the project will definitely include the object of reading disorders, dyslexia.

Summing up the tasks for child's language research, it is clearly seen that the national mission of this branch is to form stable a field of child language research in Latvia, the first results of this research provide basis for pedagogical recommendations and linguistic findings. The group of researchers of child language carries out the educational and culture-formation mission of this branch because by publishing the results of child language research the origin of our mentality and cultural identity is shown. It is as if we approach the origins of language, when people from the world of silence had to find a way for expressing experience in words. Implementation of this mission includes also popular-scientific publications, seminars, lectures and other readings so that the acquired scientific conclusions could be used also by educators of pre-school education institutions, teachers and parents. "Both the inheritance and skilful activity of the environment (parents) are very important creating good preconditions for substantial acquisition of language. Many signs show that child can inherit not only art and music but also language trends and talents, for example, good hearing, skills of imitation (imitating type of other people's speech), type of sound, visual or motor memory, even tempo of speech, as well as specific abilities of reasoning to analyse and creatively form one's expression. However, no child alone can develop these skills and will not fully learn the language of his parents and grand-parents if he will be denied the possibility to hear this language every day and grow together and through this language also spiritually. Parents' experience and teacher's methods can be of great assistance facilitating this important and complicated acquisition of the first language," so the significance of parents' and teachers' activity for development of child's language was described by Velta Rūḳe-Draviṇa (Rūḳe-Draviņa 1982, 409). Researches of child's language give basis for parent consultations; therefore centre workers take floor at parents' meetings telling about the research results. "The fact that the child reads or speaks slowly does not yet mean that the child is underdeveloped. Maybe at that moment his abstract or logic thinking and other skills are well developed. That is the so called case of hidden talents. Educated parents can help their child at its development, but also parents who have not managed to get much education themselves, can have talented children. How to find this out? What to do? To consult doctors, teachers, psychologists is necessary, but the parents themselves should facilitate development of their child, should try to help the child to acquire the basic knowledge and basic skills, so that the child can live in this world, as well as they should motivate his unique, individual development. Even if the parents might think that the child is hopelessly underdeveloped, he is the beloved darling of his parents, and such love must definitely find some significant support for his development" (Markus 2003, 141). Implementing the mission of international significance, researchers of child's language from Latvia acquire possibilities to take part in international projects, conferences and congresses on child language research, a perspective for comparative, contrastive and typological researches is formed.

In 2008, the scientists from the Child's Language Research Centre of the RTTEMA have continued to publish their research within fields envisaged by the centre concept (I. Degtjarjova, D. Dzintere, I. Freiberga, J. Grigorjevs, M. Kaltigina, A. Kauliṇa, V. Kuzina, D. Markus, A. Tauriṇa, L. Tidriķe, S. Tūbele, A. Vulāne, D. Zariņš, T. Zīrina,a), as well as they have submitted several works for publishing; by the end of the year, a book Child Language in Innovation and Play by D. Dzinteres, I. Freibergas un D. Augstkalnes can be expected, as well as the work"Dictionary of Child's Language" by I. J. Freidenfelda, D. Markus un D. Lapānes, which has been edited by A. Vulāne. Together with the eldest daughter, the researcher S. Lazdina has collected and analysed the youngest daughter's speech written recordings. An internationally edited 
journal manuscript is prepared, which plans to publish articles by I. Freibergas, M. Kaltiginas, V. Kuzinas, D. Markus, A. Taurinas, L. Tidrik̦es and T. Zīrinas regarding Latvian child's language, as well as articles by foreign authors S. Ceitlina (State Pedagogical University of Russia named after Herzen, St. Petersburg, Russia), I. Dabašinskiene (Vytautas Magnus University, Kaunas, Lithuania), Mahdalynas Lylas and Mikola Lylas (State Pedagogical University of Pereyaslav-Khmelnytskyi named after Hryhoriy Skovoroda, Pereyaslav-Khmelnytskyi, Ukraine) and articles by researchers from Tartu University in Estonia. Authors have not only described the features of child's language in the first edition of the journal; they have also marked differences between child's and adolescent's language. D. Dzintere continues research on child's colloquial speech reviewing children's questions and answers in uniform communication process; results of the research are expected to be published in a book in 2009. Especially fruitful research results were published at scientific conferences in 2008: on March 13-15 at international conference "Theory for Practice in Education of Modern Society", researchers from the Riga centre read nine reports, at international conference "Balts Languages and White Nights" in St. Petersburg on June 19-20 two reports read, at international conference "Actual Problems at Psycho-linguistics" in Pereyaslav-Khmelnytskyi on 15 October, one report read, in "The Fifth International Conference on Youth Language" in Copenhagen on March 27-29 one report read, at international seminar "Sonderpedagogische Forderung im Spanungsfeld von Rehabilitation, Integration, Inklusion" in Leipcig on March 19 one report read, at international conference "Problems of Child's Language - 2008" in St. Petersburg on March 19-21 one report read, at international conference "Man in Language Universe" in Kaunas on 9 October one report read. Names of conferences show that the linguistic and pedagogical researches launched at the Child's Language Research Centre of the RTTEMA are continued, but the sphere of research is expanded by analysis of adolescent's language, as well as solutions for child's language development and improvement are being searched in psychology and defectology, using the first findings on possibilities of cooperation between psychologists and speech therapists in Latvia (Tūbele, Kaulin,a 2007, 111-120).

\section{Conclusions}

As a result of activities of the Child's Language Research Centre of the Riga Teacher Training and Educational Management Academy research of child' language in Latvia has developed into purposeful and stable field of research.

This is a complex field of research based on results acquired by specialists from pedagogy, linguistics and psychology.

Language serves needs of child's expression and communication in compliance with the individual world of emotions, concepts, initial notions and attitude. To study this particularity and its gradual alignment with mental activities of grown-up people is a significant research task providing contribution to development of linguistics and pedagogy as well as other fields related to child's raising and development.

\section{References}

1. Claparede, E. (2008). Preface. In: Piaget J. The Language and Thought of the Child (pp. ix-xvi). The third edition. London and New York.

2. Dzintere, D., Stangaine, I. (2005). Rotaḷa - bērna dzivesveids [Games - A Child's Lifestyle]. Rïga: RaKa (in Latvian).

3. Freiberga, I. (2006). Dzimtās valodas devalvācija un bērna attīstība pirmsskolas vecumā empīrisko vērojumu un teorētisko atzin,u aspektā [Devaluation of the Native Language and the Child's Development During the Preschool Age as Seen from the Point of View of Empirical Observations and Theoretical Conclusions]. In: Teorija praksei mūsdienu sabiedrïbas izglïtībā: RPIVA starptautiskas zinātniskas konferences materiāli (133.138. Ipp.). Rìga: ULMA (in Latvian). 
4. Freidenfelds, I. (2006). Bērnu vairākvalodība kā laikmeta zīme [Children's Multilingualism as a Mark of the Epoch]. In: Teorija praksei mūsdienu sabiedrības izglīīibā: RPIVA starptautiskas zinātniskas konferences materiāli (139.143. Ipp.). Rīga: ULMA (in Latvian).

5. Markus, D. (2007). Bērns runā kultūras pasaule [A Child Speaks in the World of Culture]. Rīga: Rasa ABC, 159 Ipp. (in Latvian).

6. Markusa, D., Bērziña, I. (1991). Dzimtās valodas izjūta [The Feeling of the Native Language]. In: Estētiskā audzināšana sākumskolā (102.-108. Ipp.): LU zinātniskie raksti. Rīga: LU (in Latvian).

7. Markus, D. (1991). Bērnu valodas emocionālais potenciāls [The Emotional Potential of the Children's Language]. In: Estētiskā audzināšana sākumskolā (92.-101. Ipp.): LU zinātniskie raksti. Rīga: LU (in Latvian).

8. Markus, D. (1997). Bērna radošā valodnieciskā darbïba [Child's Creative Linguistic Activity]. In: Sapere aude (33.37. Ipp.): RPIVA zinātniskie raksti. Rīga: Vārti (in Latvian).

9. Markus, D. (2000). Valodnieciskas darbības iedīgli bērna valodiskajā darbībā [Seeds of A Linguistic Activity in the Child's Linguistic Activities]. In: Bērna audzināšana demokrātiskajai sabiedrïbai: starptautiskas konferences materiāli (148.-152. Ipp.). Rīga: Izglítības soḷi (in Latvian).

10. Markus, D. (2002). Kopīgais un atšķirīgais bērnu valodā [The Common and the Different in Children's Language]. In: Izglïtības zinātnes un pedagoǵija mūsdienu pasaulē (347.-353. Ipp.): LU zinātniskie raksti. Rīga: LU (in Latvian).

11. Markus, D. (2003). Bèrna valoda: no pirmà kliedziena lïdz pasakai [A Child's Language: From the First Cry to the Fairy-Tale]. Rīga: Rasa ABC, 144 lpp. (in Latvian).

12. Markus, D. (2006). Valoda ievada bērnu kultūrā [A Language Introduces the Child to the Culture]. Latvijas Avizze, nr. 177 (2728), 21. Ipp. (in Latvian).

13. Markus, D., Degtjarjova, I. (2006). Termini bērna valodā [Terms in the Child's Language]. In: Teorija praksei mūsdienu sabiedrības attīstībā: starptautiskas zinātniskas konferences materiāli (306.-311. Ipp.). Rīga: SIA ULMA (in Latvian).

14. Markus, D., Degtjarjova, I., Grigorjevs, J. (2007). Bērna valodas pētniecība Latvijā [Studies of the Child's Language in Latvia]. In: Vecuma grupu valodas ipatnïbas Latvijā: lingvistiskais, sociālais un kultūras aspekts. Bērnïba (9.16. Ipp.). Rīga: Izglïî̉bas soḷi (in Latvian).

15. Markus, D. (2008). Jēdzieni bērna valodā un attēlā [Concepts in the Child's Language and Images]. In: RPIVA 4. starptautiskās zinātniskās konferences "Teorija praksei mūsdienu sabiedrības izglīīīā" materiāli (220.224. Ipp.). Rīga (in Latvian).

16. Markus, D. (2008). Jēdziens bērna valodā un zimmējumā [Concepts in the Child's Language and Drawings]. In: Latvijas Avize, 128 (3383), 12.05.2008, 16. Ipp. (in Latvian).

17. Markus, D. (2008). Bērna valoda un vērtību pārdzìvojums [The Child's Language and Emotional Experiences of Values]. In: LU raksti, 728. sējums „Valodniecïba. Latvistika” (92.-97. Ipp.). Rīga: LU Akadēmiskais apgāds (in Latvian).

18. Markus, D., Grigorjevs, J. (2008). Bērna valodas pētniecība valodas apguves kontekstā [Studies on the Child's Language within the Context of Language Learning]. In: Tagad: LVAVA zinātniski metodisks izdevums, 1.2008, 5.-12. Ipp. (in Latvian).

19. Ruke-Dravina, V. (1967). Mehrsprachigkeit im Vorschulalter. Lund: Gleerup, S. 104.

20. Rūķe-Draviña, V. (1982). No pieciem mēnešiem lìdz pieciem gadiem [From Five Months to Five Years]. Stokholma (in Latvian).

21. Rūkse-Dravina, V. (1993). Latviešu meitene apgūst savu pirmo valodu [A Latvian Girl Learns Her First Language]. Rīga, Dio Nordik, 3, 112 lpp. (in Latvian).

22. Rūḳe-Draviṇa, V. (1995). Pasaka par Sarkangalviti vecāku un bērnu stāstīumā [A Fairy Tale about Red Riding Hood as Told by Parents and Children]. Apkārtnes ietekme valodas attīstībā. Rīga: Rīgas Pedagoǵijas un izglītības vadïbas augstskola, 35 Ipp. (in Latvian).

23. Ruke-Dravina, V. (1963). Zur Sprachentwicklung bei Kleinkindern. In: Beiträge auf der Grundlage litteschen Sprachmaterials (S. 178). Lund: Slavinska inst. Vid Lunds univ.

24. Vecmane, S. (2006). Skaitāmpanti, rīmes un dzejoli - harmoniskai attīstībai [Nursery Rhymes, Rhymes and Poems - for a Harmonious Development]. Izglïtiba un Kultūra, 2006. gada 27. jūlijs, 12. Ipp. (in Latvian). 
25. Vulāne, A. (2006). Bērnu izmantotie paṇēmieni okazionālismu darināšanā [Methods Used by Children in Creating Occasionalisms]. In: Teorija praksei mūsdienu sabiedrības izglîtībā: RPIVA starptautiskas zinātniskas konferences materiāli (522.-526. Ipp.). Rīga: ULMA (in Latvian).

26. Маркус, Д. (2007). Как образовывают, выбирают и классифицируют дети в латышском языке [How Children Create, Choose and Classify in the Latvian Language]. In: Проблемы онтолингвистики - 2007: материалы международной конференции. Санкт-Петербург: «Златоуст», с. 137.-138. (in Russian).

27. Маркус, Д., Букша, И. (2007). Отражение ценностей и отношений в языке детей при эмоциональном восприятии сказок [Depiction of Values and Attitudes in Children's Language in the Emotional Process of Perception]. In: Kida, J. (ed.) Kultura, literatura i sztuka w edukacji jezykowej w swietle badan empirycznych (s. 280286). Rzeszow: Wydawnictwo Uniwersyteto Rzeszowskiego (in Russian).

\section{Prof. Dr. habil. philol. Dace Markus}

Riga Teacher Training and Educational Management Academy Address: Imantas 7. linija 1, Riga, LV-1083, Latvia

Phone: (+371) 67860682

E-mail:markus@latnet.lv 